\title{
STRENGTH CALCULATION OF AN INDUSTRIAL HALL WITH A GANTRY CRANE
}

\author{
Article DOI: $\underline{\text { https://doi.org/10.35219/mtd.2018.3.03 }}$ \\ Carmen MICU \\ Department of Mechanical Engineering, University “Dunarea de Jos” of Galati, Romania \\ e-mail: carmen.micu@yahoo.com
}

\begin{abstract}
The analysis shows that the profiles play an important role in the displacement values due to static stresses. The results obtained in the industrial parter floor show the structure's ability to withstand standard wind and snow loads, but also after a possible earthquake. After the static analysis, values close to the norm-accepted limit were recorded. The advantage of metallic constructions in the field of industrial halls is obvious: weight reduction compared to reinforced concrete constructions; increased safety due to the homogeneity of steels; reduced execution time, etc. In combined cases for determining the ultimate fundamental load the maximum combined bending stresses and axial stresses do not exceed the $150 \mathrm{MPa}$ admissible stress; the largest combined stresses are recorded in the bundles and not the length of the bars, with regard to the welding connection of the bar elements (roof and upper longitudinal bracings).

The maximum total displacements of the rolling bridge are in accordance with the applicable regulations (arrow / bar length <1/600). Relative displacements greater than 1/600 are recorded in bars without technological importance. The track of the bridge is relatively less influenced by the action of the external loads of the hall, it is supported by its own pillars.

It is absolutely necessary to take into account the effects the snow loads, wind pressure, seismic activities can have on the structure, and an important task that must be taken into account is their own weight because the structure can cede only by the action of this task without the involvement of other external forces.
\end{abstract}

Keywords: profiles, static stress, snow load, wind pressure, displacements, seismic activity

\section{ACTIONS TO WHICH FARMS ARE SUBJECT TO}

Farms used in industrial metal halls are part of their structure, forming spars [rods] of the resistance structure. Depending on the connection between the spar framework and the pillars of the structure, the farms receive different loads from the actions on the structure as a whole [1], [2], [3].

Actions directly applied to the farms of a metallic transverse structure may come from:

- roof weight (cover, reinforcement) and farm weight,

- industrial dust deposited on the roof of the hall;

- snow;

- wind, which acts on some elements of the roof,

- actions from lifting and transport means supported by farms;

- earthquake, which can also cause some direct effects.

Some of these actions are permanent, others are variable, temporary, which may be long-lasting or short-lived, temporary actions may have a high frequency of high or low values [5], [11].

For some of these actions, the normative values are provided by the load standards, for others the project team has to determine them based on the technological elements. In order to choose the type of farm, rigidity tests were carried out on a single openair ground floor industrial hall. The English type was realized because it is the case with the highest stiffness according to [1], [10].

\section{THE STRUCTURE OF A HULL FOR HANDLING AND STORAGE NAVAL SUBASSEMBLIES AND LOADS}

The study aims at calculating the strength and rigidity of a one-sided ground floor industrial hall with the dimensions shown in Fig. 1 (gantry crane is not shown).

\section{Permanent load}

In the case of the hall, the permanent load caused by [4]: 


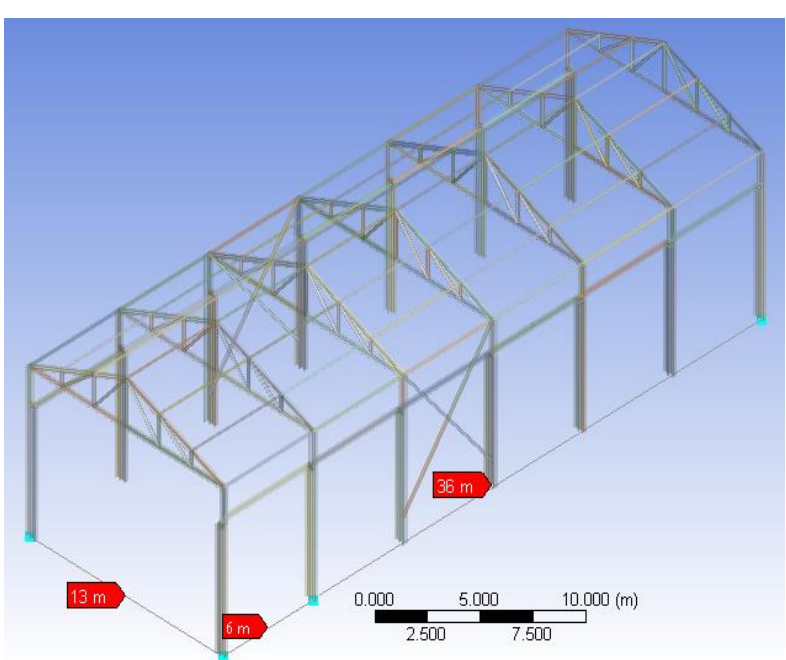

Fig. 1. One-sided ground floor industrial hall

- the weight of the main metal structure is automatically included in the ANSYS workbench program [6], [7], [8], [9].

- the weight of the cover, determined from the data in the catalogs supplied by the manufacturer (cut sheets, insulation materials, pans)

- the weight of the closure walls, determined using the catalogs provided by the manufacturer (cut sheets, insulation materials, wall rods). Also, there is no need to provide tension rods in the roof plan, which (for classic systems) may appear necessary to create additional supports at the minimal axis of inertia of the panels.

The disadvantages of the system are the increased workload during assembly and the presence of thermal bridges along the panels / rods (although the system provides local thermal insulation strips, arranged on the outside of the pan / rod, to reduce this effect).

Calculation of the standard value of permanent load in the cover gave $20 \mathrm{daN} / \mathrm{m}^{2}$. Calculation of the standard value of the permanent load from the closing walls gave $17 \mathrm{daN} / \mathrm{m}^{2}$.

\section{Calculation of normal snow load}

The normalized load distribution from snow [4] is determined according to STAS 10101/21-92 with the relation:

$$
p_{z}^{n}=c_{z i} \cdot c_{e} \cdot g_{z}=1.5 \cdot 0.8 \cdot 1.0=1.2 \mathrm{kN} / \mathrm{m}^{2}
$$

where $g_{z}=1.5 \mathrm{kN} / \mathrm{m}^{2}$ (reference weight of snow for a 10 years period, in Galati, snow zone C), $c_{e}=0.8$ (exposure coefficient for normal conditions, with flat roof and low influence); $c_{z i}=1.0$ (coefficient of snow aggomeration on the construction surface).

Distributed snow load per linear ruler of the current frame (taking into account that the trajectory of the hall of a value $\mathrm{T}=6.0 \mathrm{~m}$ ) results:

$$
q_{z c}=p_{z}^{n} \cdot T=1.2 \cdot 6.0=7.2 \mathrm{kN} / \mathrm{m}
$$

Distributed snow load per linear meter of the front frame ruler:

$$
q_{f}=p_{z}^{n} \cdot \frac{T}{2}=1.2 \cdot 3.0=3.6 \mathrm{kN} / \mathrm{m}
$$

\section{Loads from wind}

The normal intensity of the normal component at the exposed surface is determined according to STAS 10101/20-90 with the relation [4]:

$$
p_{n}^{n}=\beta \cdot c_{n i} \cdot c_{h}(Z) \cdot g_{v}
$$

where the factors in the right member of the relationship have the following meaning: $\beta=1.6$ (bursting coefficient for a current, less wind-sensitive construction, category $\mathrm{C} 1), c_{n i}$ - aerodynamic coefficient on the "i" surface determined according to standard, $c_{h}(Z)=1.0$ (coefficient of variation of the basic dynamic pressure in relation to the height above the ground for a type I site $\rightarrow$ locations in the area built with obstacles with heights smaller than $11.6 \mathrm{~m}$ ), $g_{v}=0.55 \mathrm{kN} / \mathrm{m}^{2}$ (the basic dynamic pressure at a height of $11.6 \mathrm{~m}$ above the ground in Galaţi - wind zone C, determined for a 10 -year return period).

The value of safety coefficient of wind load for Class III buildings was determined for a category $\mathrm{C} 1$ construction located in the $\mathrm{C}$ wind zone [4].

The values of the distributed loads of the longitudinal and transverse wind loads used in the finite element analysis are:

- aerodynamic coefficients and normal pressures at the cross-wind area of the hall (Table 1),

- aerodynamic coefficients and normal wind pressure conditions according to the longitudinal direction of the hall (Table 2).

Table 1

\begin{tabular}{|c|c|}
\hline Normal surface pressure & $\begin{array}{c}\text { Uniformly } \\
\text { distributed load }\end{array}$ \\
\hline $\begin{array}{c}p_{n 0}^{t}=1.6(+0.8) \cdot 1.0 \cdot 0.55= \\
0.70 \mathrm{kN} / \mathrm{m}^{2}\end{array}$ & $q_{n 0}=2.2 \mathrm{kN} / \mathrm{m}$ \\
\hline $\begin{array}{c}p_{n 1}^{t}=1.6(-0.18) \cdot 1.0 \cdot 0.55= \\
0.16 \mathrm{kN} / \mathrm{m}^{2}\end{array}$ & $q_{n 1}=-0.47 \mathrm{kN} / \mathrm{m}$ \\
\hline $\begin{array}{c}p_{n 2}^{t}=1.6(-0.4) \cdot 1.0 \cdot 0.55= \\
-0.35 \mathrm{kN} / \mathrm{m}^{2}\end{array}$ & $q_{n 2}=-1.037 \mathrm{kN} / \mathrm{m}$ \\
\hline$p_{n 3}^{t}=1.6(-0.5) \cdot 1.0 \cdot 0.55=$ & $q_{n 3}=-1.44 \mathrm{kN} / \mathrm{m}$ \\
$-0.44 \mathrm{kN} / \mathrm{m}^{2}$ & \\
\hline
\end{tabular}

Table 2

\begin{tabular}{|c|c|}
\hline Normal surface pressure & $\begin{array}{c}\text { Uniformly } \\
\text { distributed load }\end{array}$ \\
\hline $\begin{array}{l}p_{n 0}^{t}=1.6(+0.8) \cdot 1.0 \cdot 0.55= \\
0.70 \mathrm{kN} / \mathrm{m}^{2}\end{array}$ & $q_{n 0}^{1}=2.082 \mathrm{kN} / \mathrm{m}$ \\
\hline $\begin{array}{l}p_{n 1}^{t}=1.6(-0.18) \cdot 1.0 \cdot 0.55= \\
0.16 \mathrm{kN} / \mathrm{m}^{2}\end{array}$ & $q_{n 1}^{1}=-0.62 \mathrm{kN} / \mathrm{m}$ \\
\hline $\begin{array}{l}p_{n 2}^{t}==1.6(-0.5) \cdot 1.0 \cdot 0.55= \\
-0.44 \mathrm{kN} / \mathrm{m}^{2}\end{array}$ & $q_{n 2}^{1}=-1.309 \mathrm{kN} / \mathrm{m}$ \\
\hline
\end{tabular}




\section{STRENGTH CALCULATION OF THE GANTRY CRANE HULL, USING THE FINITE ELEMENT METHOD}

\section{Linear Static Analysis}

The term static load refers to load that does not include the effects of inertia forces or damping. Static analysis is linear if the nonlinearities due to large displacements and deformations, material flow, mechanical contact problems and other sources of nonlinearities are either linearized or completely ignored. The formulation of the static problem for obtaining the solution by the displacement method is described by the matrix equation:

$$
[K]\{u\}=\{F\}
$$

in which $[K]$ is the rigidity matrix of the structure, $\{u\}$ the vector of the nodal displacements, and $\{F\}$ represents the vector of the nodal forces. Nodal displacements are unknown and can be obtained by the Gauss method. The $\{F\}$ vector includes applied

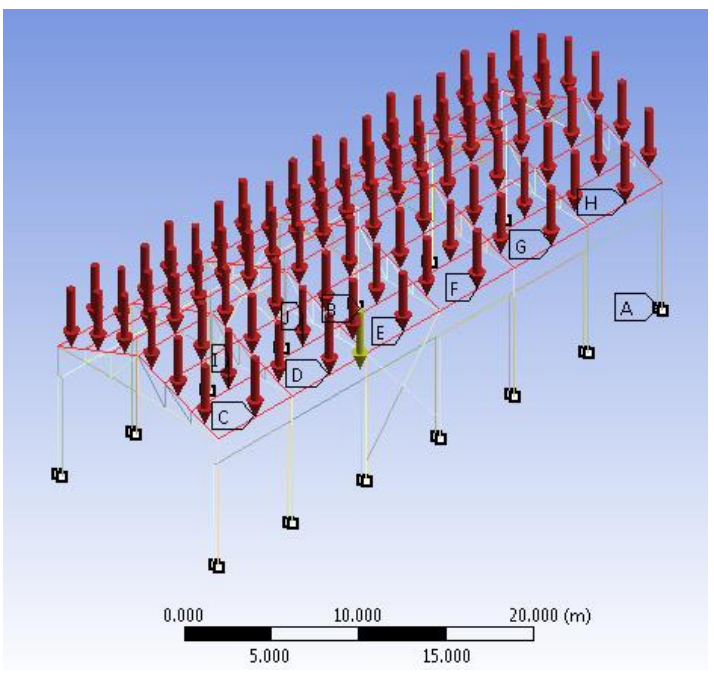

Fig. 2. Limit conditions for load 1

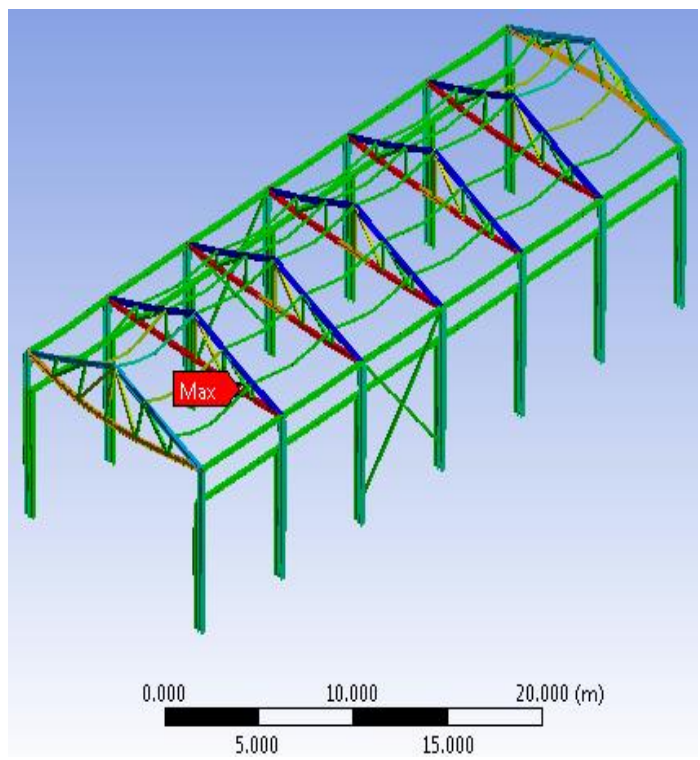

Fig. 4. Distribution of direct stresses in case of 1 forces and moments, reactions, pressures, distributed loads, own weight, thermal load.

\section{Fixed Static Load Cases for the Metallic Wheelhouse}

The static analysis of the hall was carried out on several load cases as in Table 3. The model has 1184 nodes and 647 elements.

Table 3.

\begin{tabular}{|l|l|}
\hline Case & Description of loading \\
\hline case 1 & Weight load, snow and roof \\
\hline case 2 & Normal transverse wind load \\
\hline case 3 & Longitudinal normalized wind load \\
\hline case 4 & Loading from the load of the $6.5 \mathrm{tf}$ \\
\hline
\end{tabular}

\section{Static Analysis in the Case of Loading 1}

The boundary conditions for this load case 1 (load of own weight, snow and roof weight) are shown in Fig. 2.

The results of the static analysis in this load case are shown in Fig. 3 to Fig. 7.

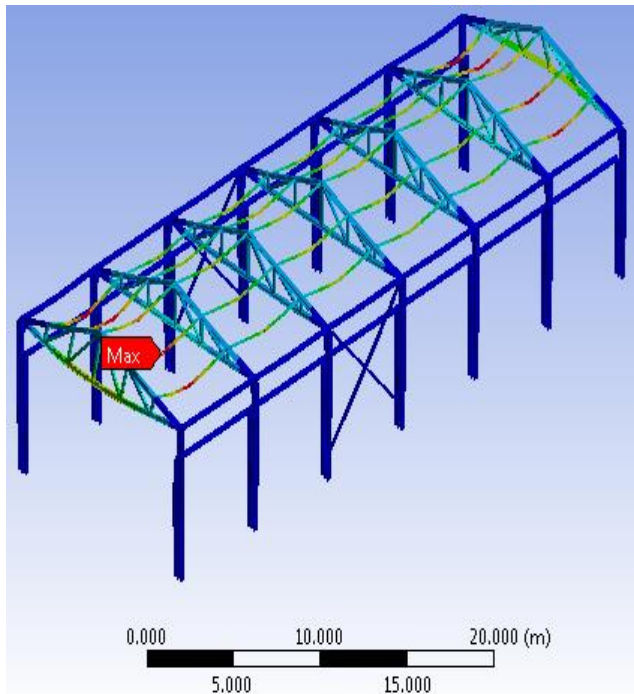

Fig. 3. Distribution of total displacements in Case 1

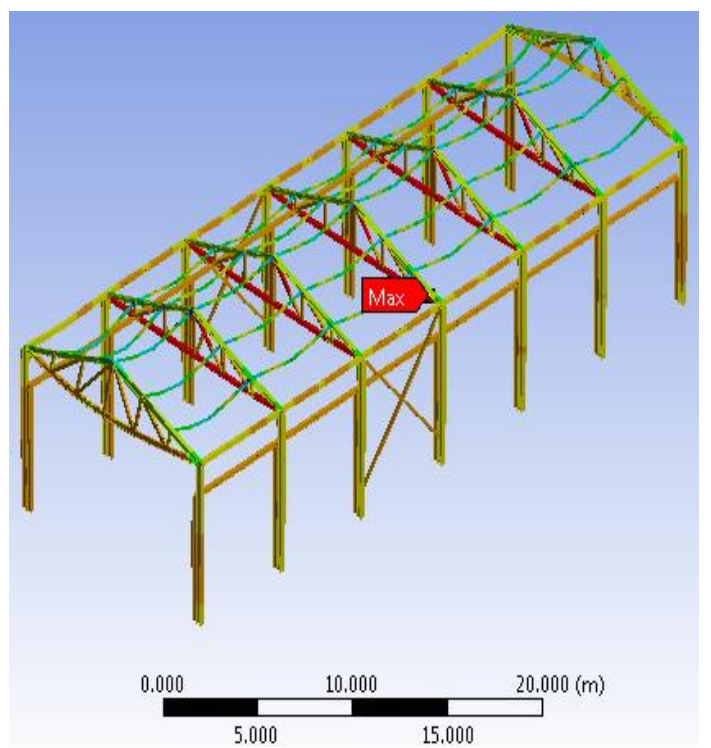

Fig. 5. Distribution of minimum combined stresses in the case of 1 


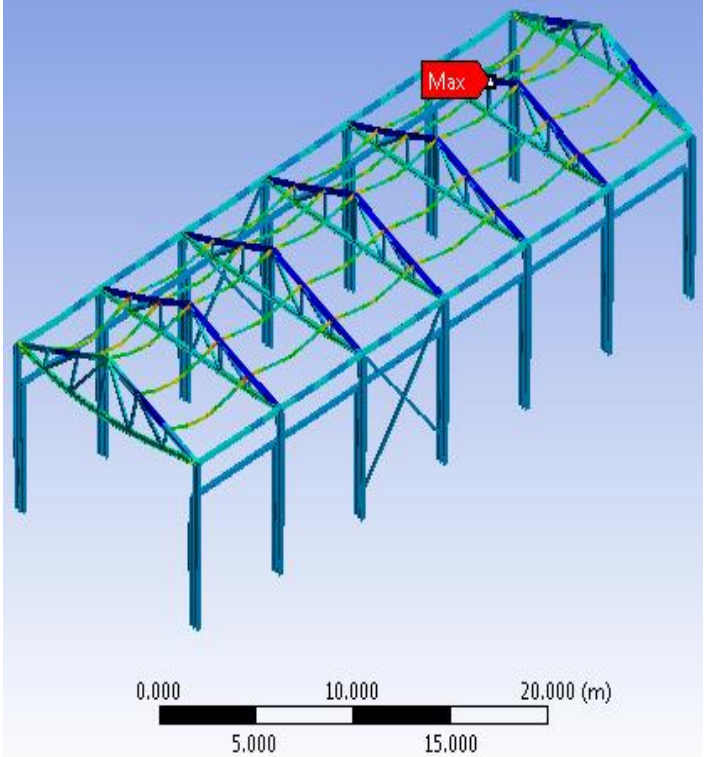

Fig. 6. Distribution of the maximum combined stresses in the case of 1

Figure 4 presents the total displacement field, the maximum displacement of $11 \mathrm{~mm}$ is recorded in the roof bracings and falls within the standard stiffness condition for this type of structural element of 1/350.

Figure 5 shows the distribution of direct stresses with a maximum of $12.3 \mathrm{MPa}$ below the allowable stress. Figure 6 shows the distribution of minimum combined stresses with a maximum of $11.3 \mathrm{MPa}$, below the admissible stress value, concentrated in the joining of lattice beams; Figure 7 presents the distribution of direct stresses with a maximum of 62.67 $\mathrm{MPa}$, value below the admissible stress.

\section{Static Analysis of the Hall in the Case 2 of Load - Standard Load from the Transverse Wind Action}

The limit conditions for this load case are shown in Fig. 8. The results of static analysis in this load case are shown in Fig. 9, Fig. 13 as follows:

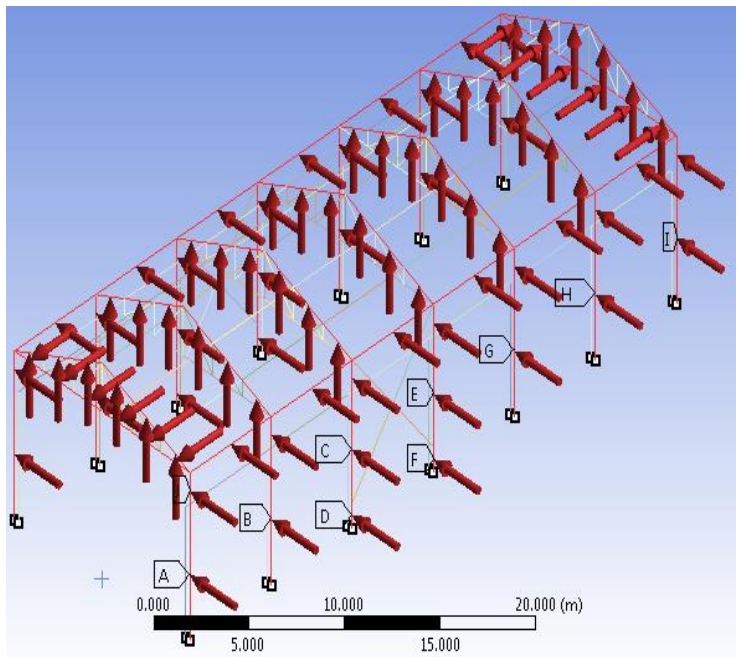

Fig. 8. Boundary conditions in case 2

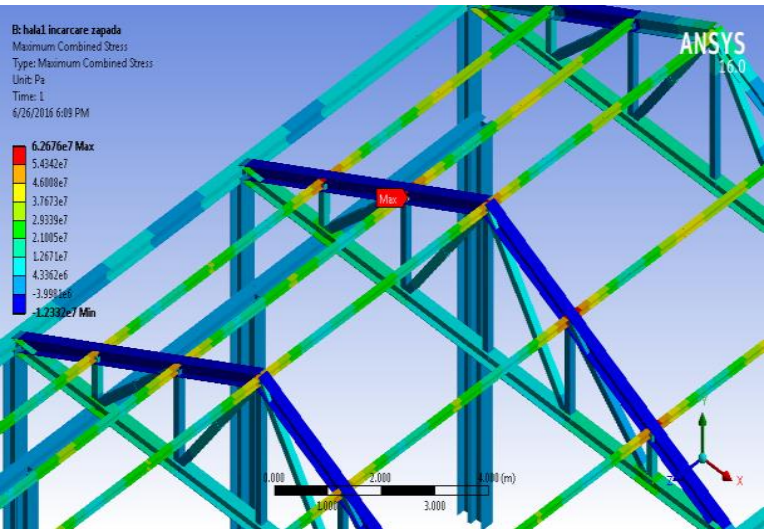

Fig. 7. Distribution of the maximum combined stresses (detail) in case 1

In Fig. 9, the total displacement field is given the maximum displacement of $31 \mathrm{~mm}$ is recorded in the bracing of the roof and falls within the standard stiffness condition for this type of structural element of $1 / 300$.

Figure 10 shows the distribution of direct stresses with a maximum of $9.7 \mathrm{MPa}$ below the allowable stress value; Figure 11 shows the distribution of the minimum combined stresses with a maximum of $8 \mathrm{MPa}$, below the admissible tension value, concentrated in the joint of the beam beams; Figure 12 shows the distribution of direct stresses with a maximum of $62.08 \mathrm{MPa}$, value below the allowable stress; a detail with the maximum stress is shown in Fig. 13.

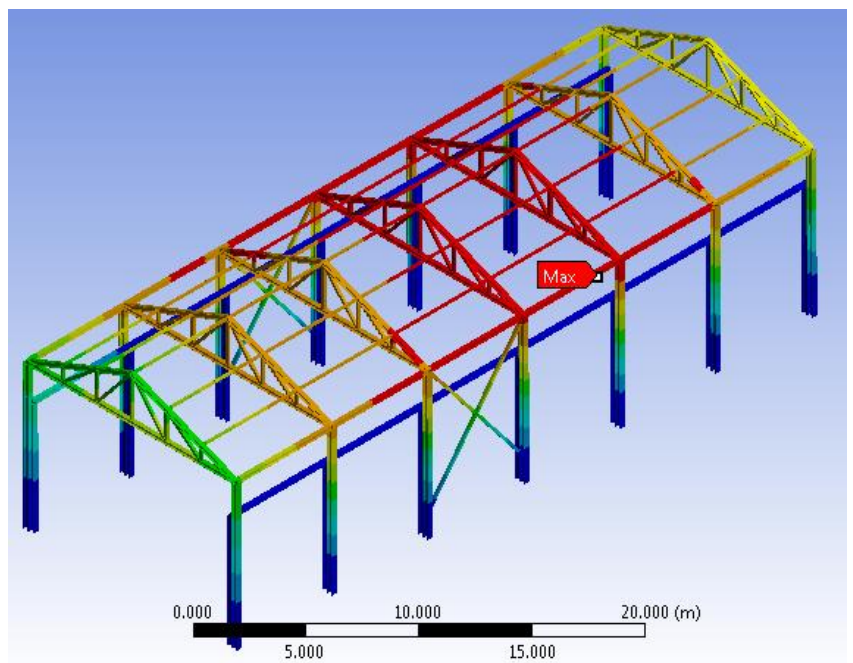

Fig. 9. Total displacement distribution in Case 2 


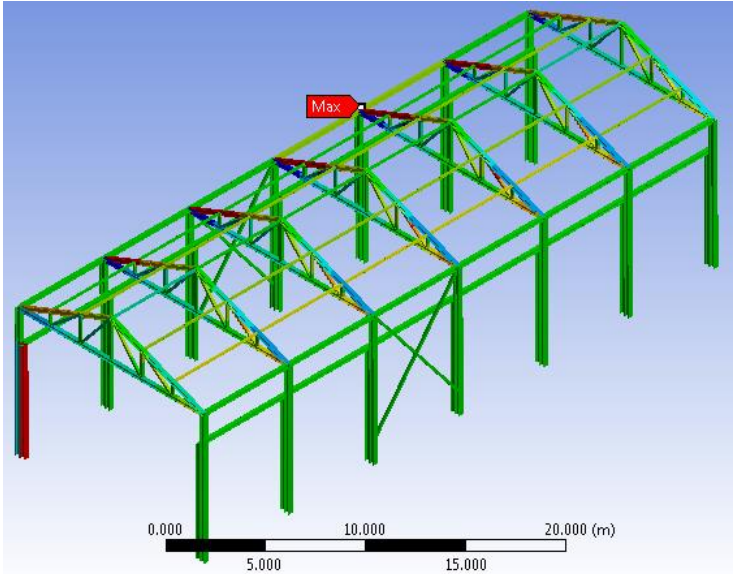

Fig. 10. Distribution of direct stresses in Case 2

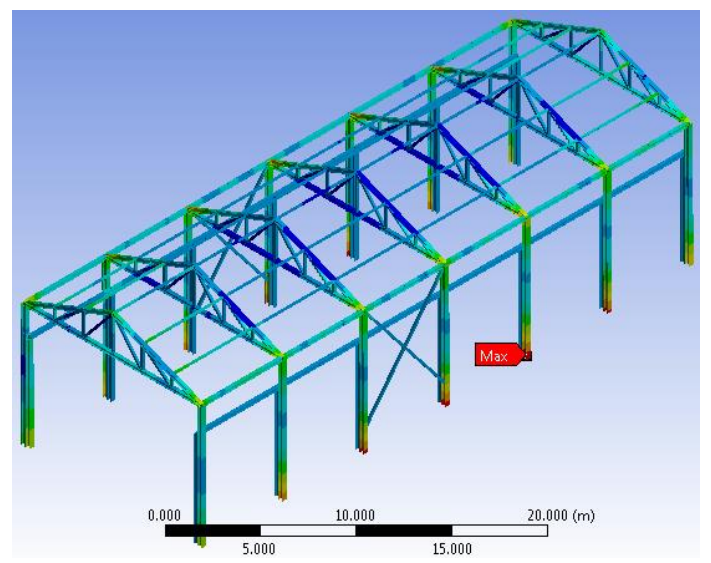

Fig. 12. Distribution of the maximum combined stresses in Case 2

\section{Static Analysis of the Hall in Case 3 of Load} Normal Load from the Longitudinal Wind Action

The limit conditions for this load case are shown in Fig. 14.

The results of the static analysis in this load case are shown in Fig. 15, Fig. 19 as follows. Figure 15 is given the total displacement field - the maximum displacement of $22 \mathrm{~mm}$ is recorded in the lattice beam and falls within the standard stiffness condition for this type of structural element of 1/300. Fig. 16

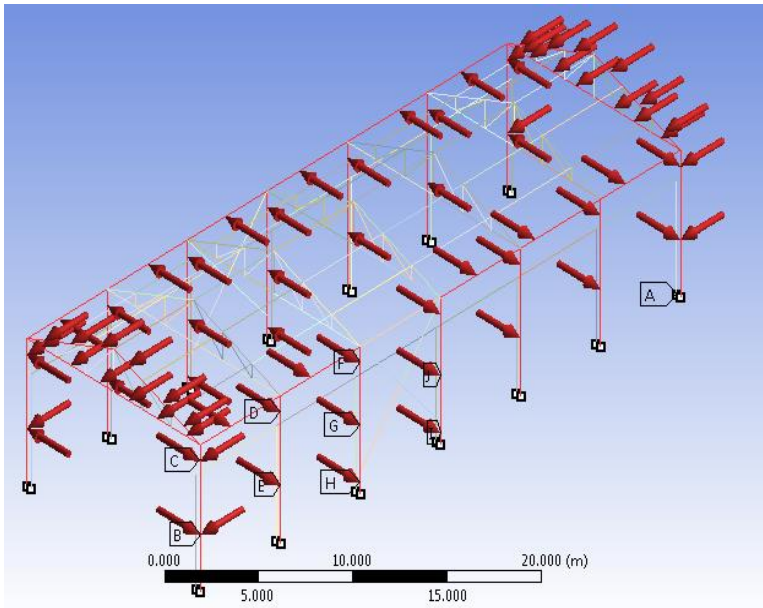

Fig. 14. Limit conditions in Case 3

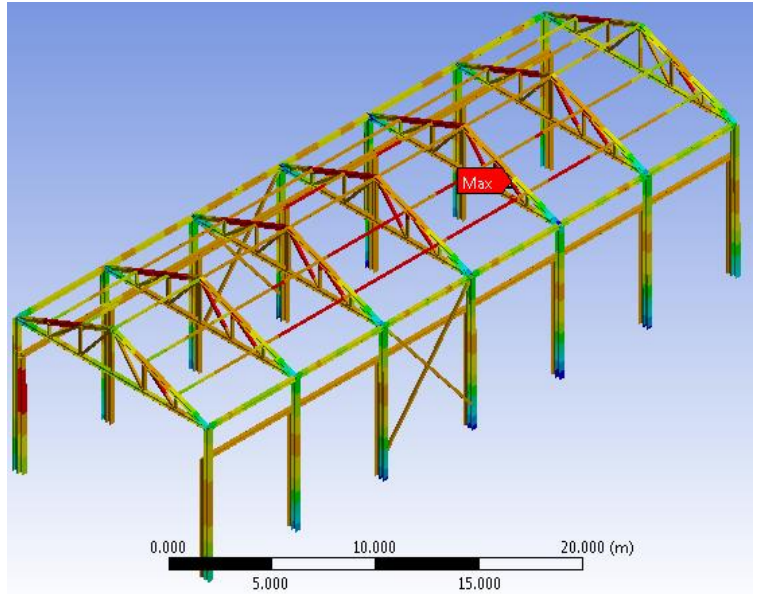

Fig. 11. Distribution of the minimum combined stresses in Case 2

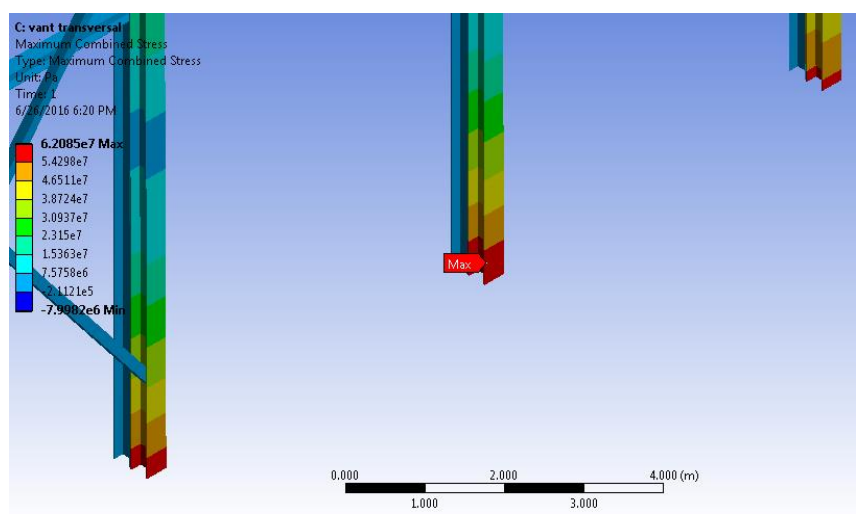

Fig. 13. Distributions of the maximum combined stess Case 2 . Detail

shows the distribution of direct stresses with a maximum of 9.63 MPa below the allowable stress value. Figure 17 shows the distribution of the minimum combined stresses with a maximum of 8.9 MPa, below the admissible stress, concentrated in the contours of the base structure. Figure 18 shows the distribution of direct stresses with a maximum of 69.97 $\mathrm{MPa}$, value under the admissible stress, concentration in the area of the main pillars; a detail with the maximum stress is shown in Fig. 19.

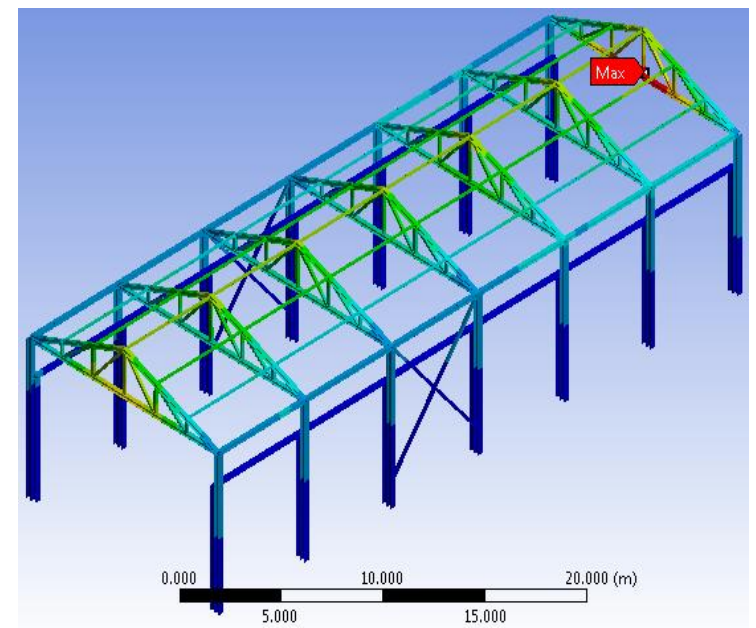

Fig. 15. Total displacement distribution in Case 3 


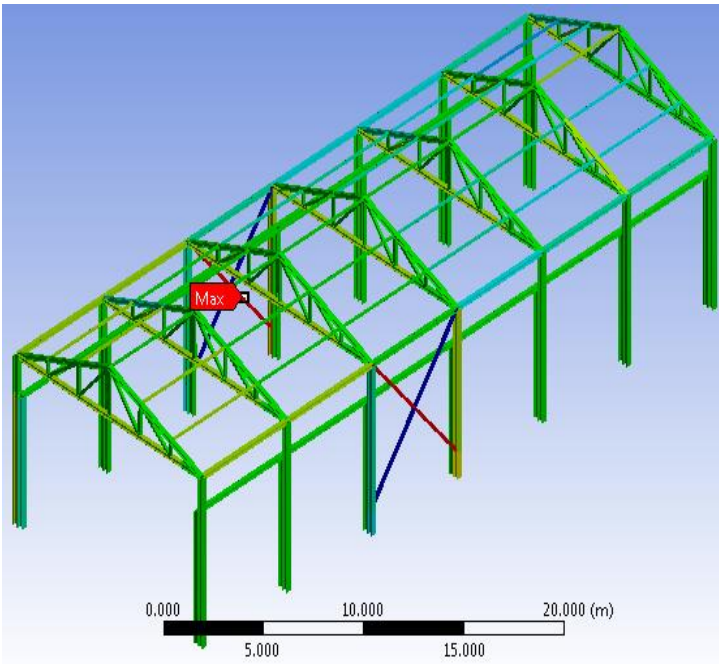

Fig. 16. Distribution of direct tensions in Case 3

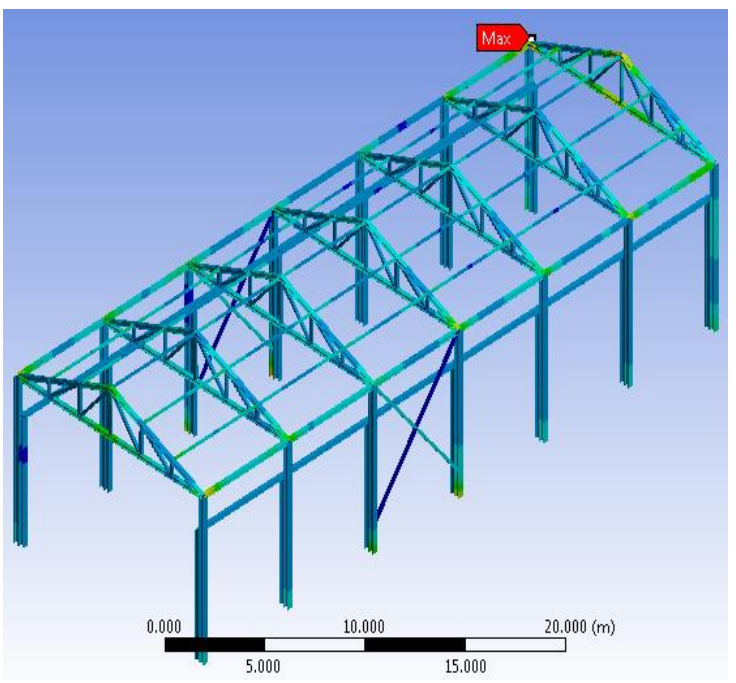

Fig. 18. Distribution of the maximum combined stresses in the Case of 3

\section{Static Analysis of the Hall in Case 4 of Load}

The limit conditions for this load case 4 (loading of own weight and action of the 6.5 tf gantry crane on the center of the hall) are shown in Fig. 20.

The results of the static analysis in this load case are shown in Fig. 21, Fig. 22 as follows: Figure 21, presents the total displacement field and the maximum displacement of $4.8 \mathrm{~mm}$ is recorded in the support beam of the rolling bridge and falls within the standard stiffness condition for this type of structural element of $1 / 600$.

Figure 22 shows the distribution of the maximum combined stresses, with a maximum of $48 \mathrm{MPa}$, value under the admissible stress, concentrated in the action area of the rolling bridge.

\section{Results of the Load Combination Calculation to Establish the Ultimate Base Condition for the Analysis Metal Shelf}

The results of the static analysis in case of 1 combination (1.1 permanent weights +2.13 snow weight) are presented in Fig. 23 - maximum total positioning and Fig. 24 the distribution of the maximum combined stresses

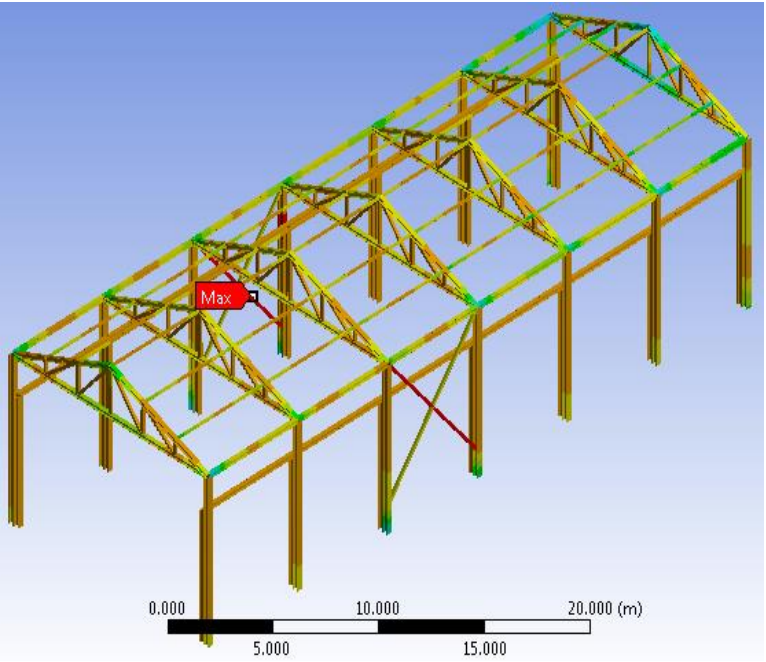

Fig. 17. Distribution of minimum combined stresses in Case 3

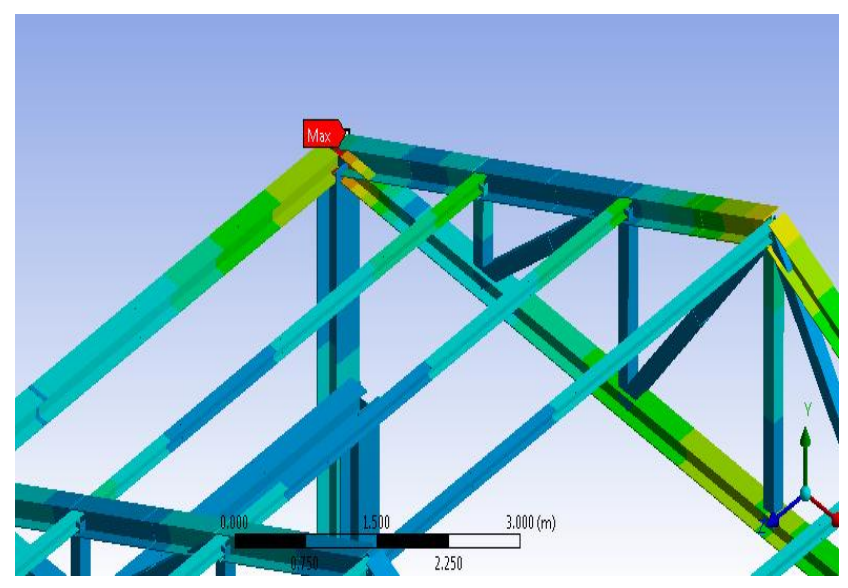

Fig. 19. Distributions of the maximum combined stresses in the cCase 3. Detail

The results of the static analysis in case of the 2 combination (1.1 Permanent weights +1.2 Useful (technological) +1.2 Transverse Strength) are shown in Fig. 25 for the maximum total displacement, Fig. 26 for the distributions of the maximum combined stresses.

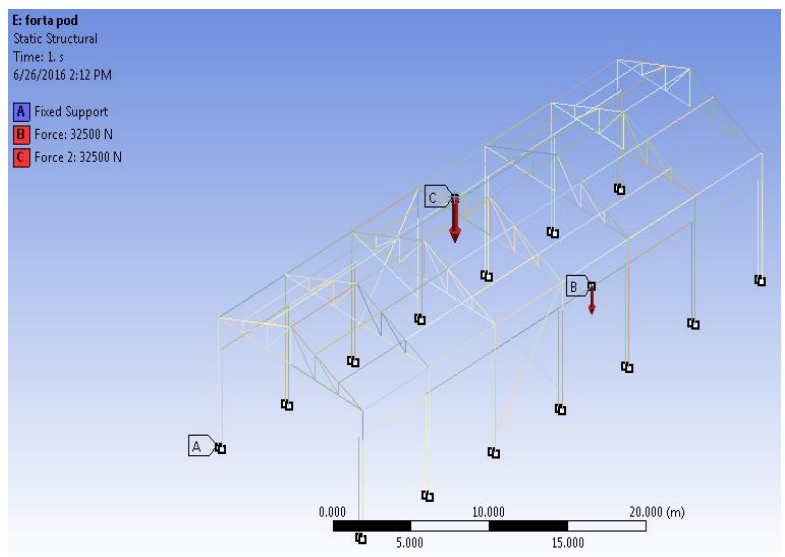

Fig. 20. Baoundary conditions for Case 4 


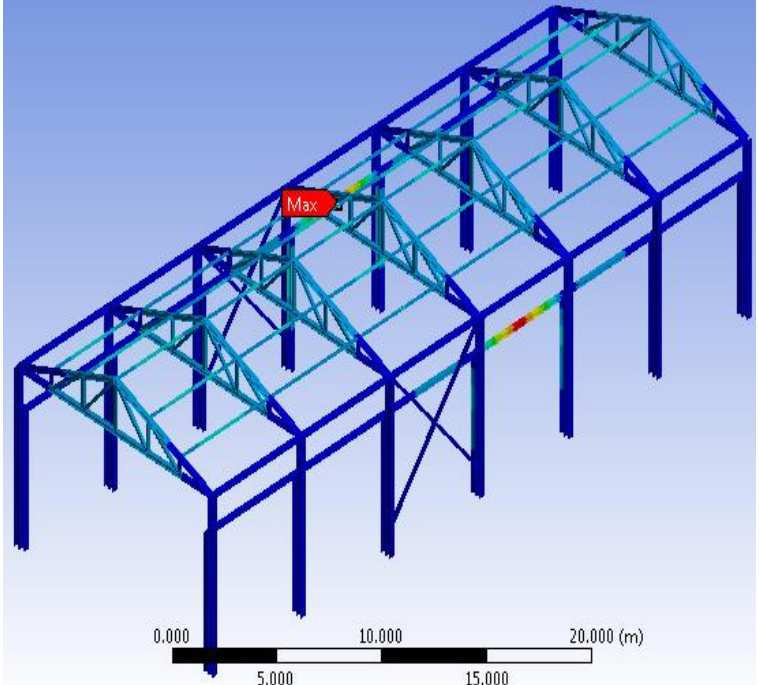

Fig. 21 Total displacement distribution in Case 4

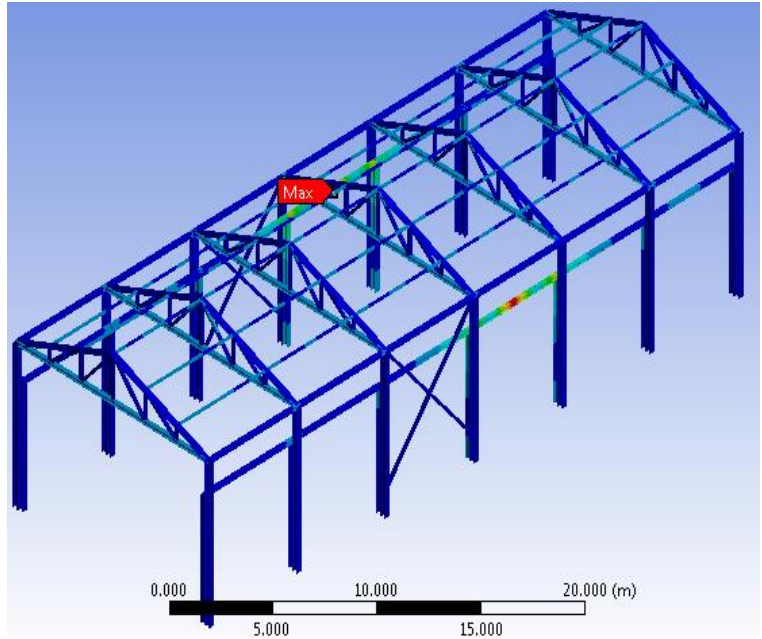

Fig. 22 Distribution of the maximum combined stresses in Case 4

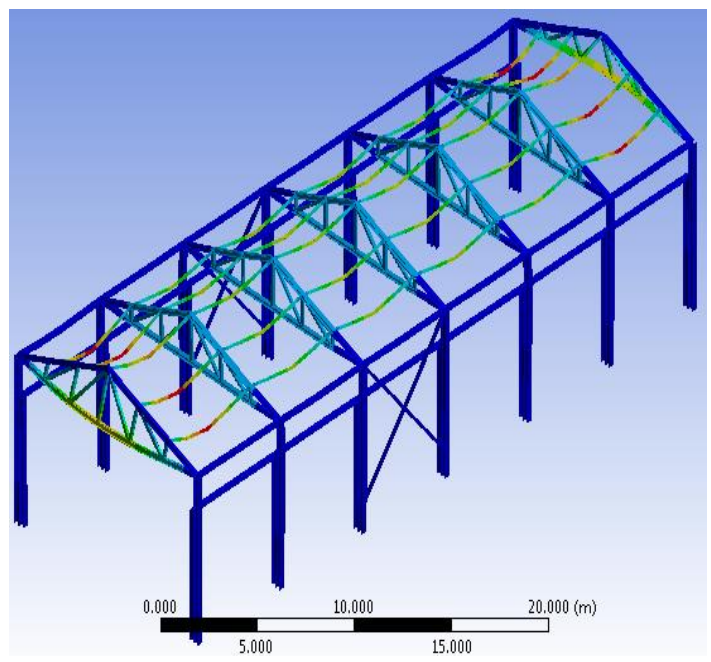

Fig. 23. Total maximum displacement for Case 1 of combinations

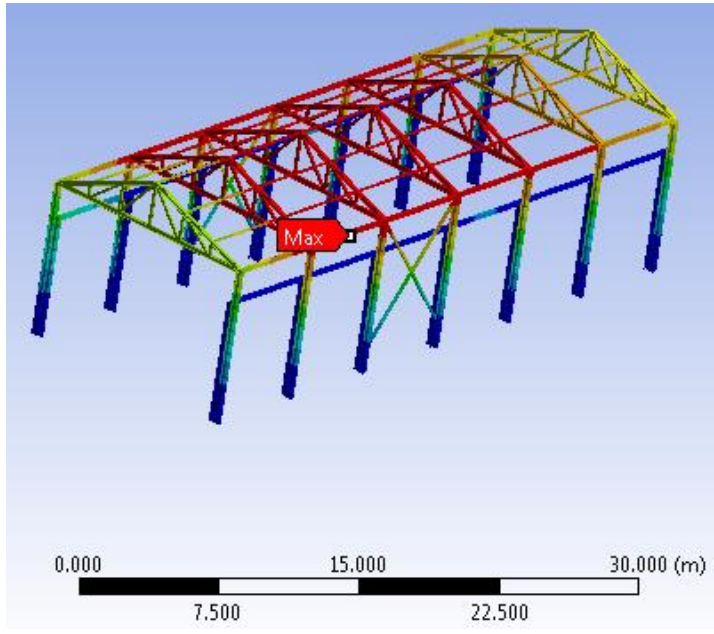

Fig. 25. Maximum total displacement for Case 2

The results of the static analysis in Case 3 of the combinations $[1.1$ Permanent weights +1.2 Technological weight +0.9 (2.13 Snow weight +1.2 Transverse wind)] are shown: in Fig. 27 total displacements are given, corresponding to stress distibution in Fig. 28.

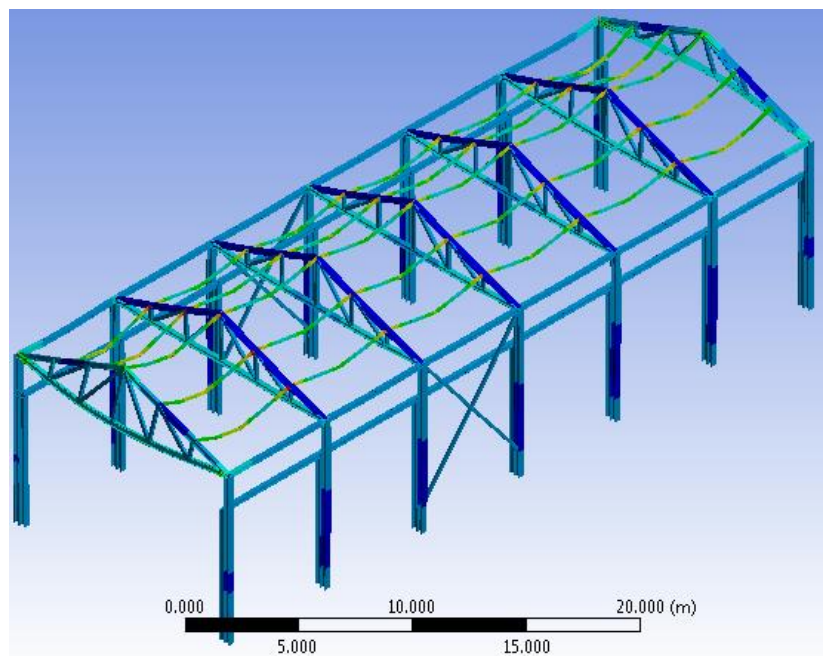

Fig. 24. Distribution of the maximum stresses in Case 1 (combined loads)

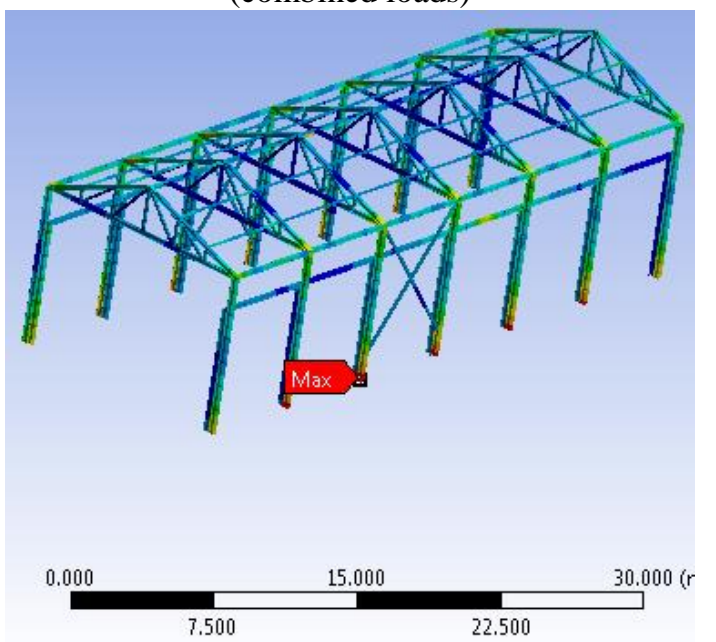

Fig. 26. Stress distribution for combined loads, Case 2

The results of the static analysis in the case of the combination 4 [1.1 Permanent weights +1.2 Useful $($ technological $)+0.9$ (2.13 Snow weight +1.2 Longitudinal wind)] are presented in the Fig. 29, for maximum total displacement and in Fig. 30 for the displacement produced by the combined loads. 


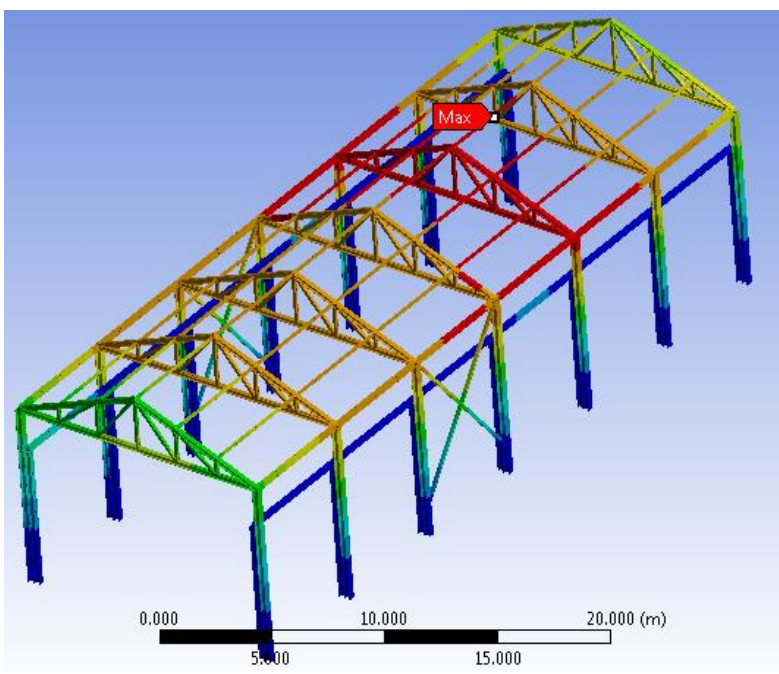

Fig. 27. Total maximum displacement Case 3

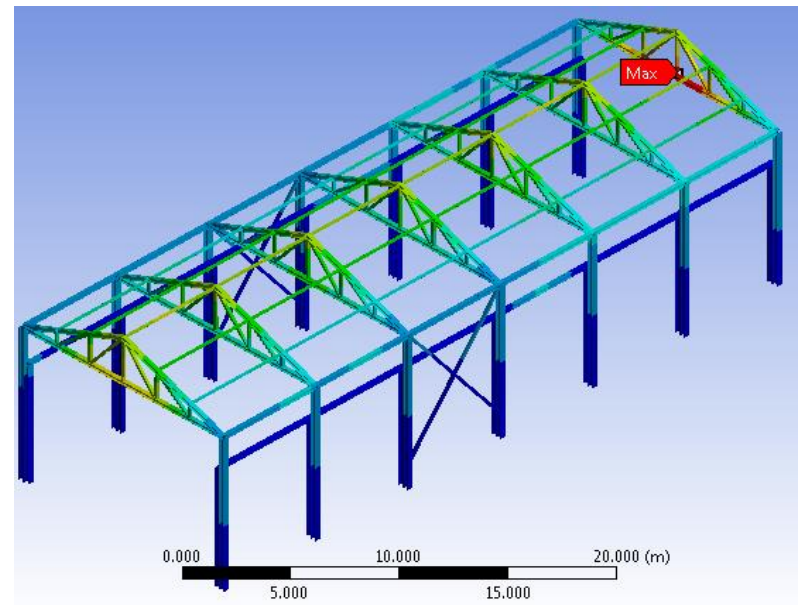

Fig. 29. Total maximum displacement, Case 4 of load combination

\section{CONCLUSIONS}

The results obtained in the industrial parter floor show the structure's ability to withstand standard wind and snow loads, but also after a possible

The advantage of metallic constructions in the field of industrial halls is obvious: weight reduction compared to reinforced concrete constructions; increased safety due to the homogeneity of steels; reduced execution time, etc.

In combined cases for determining the ultimate fundamental load the maximum combined bending stresses and axial stresses do not exceed the $150 \mathrm{MPa}$ admissible stress; the largest combined stresses are recorded in the bundles and not the length of the bars, with due regard to the welding connection of the bar elements (roof and upper longitudinal bracings).

The maximum total displacements of the rolling bridge are in accordance with the applicable regulations (arrow/bar length <1/600). Relative displacements greater than $1 / 600$ are recorded in bars without technological importance. The track of the bridge is relatively less influenced by the action of

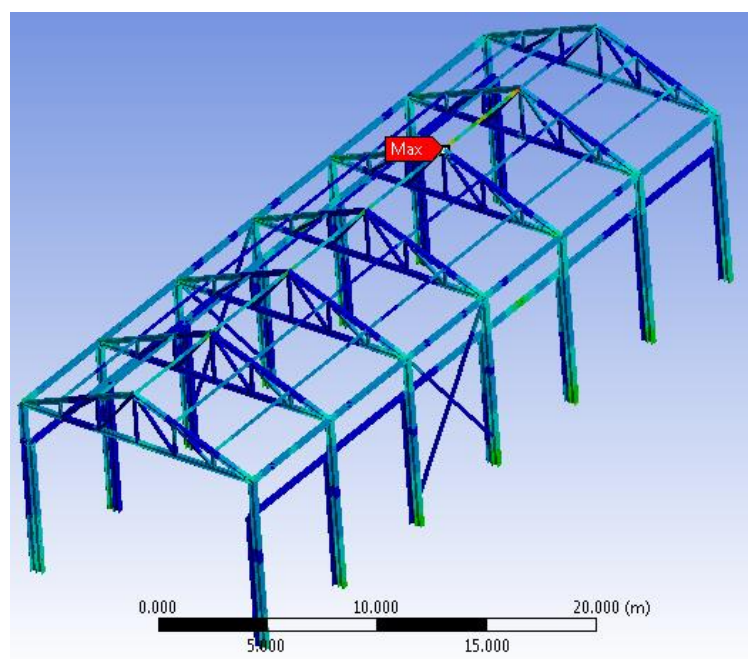

Fig. 28. Distribution of maximum combined stresses Case 3

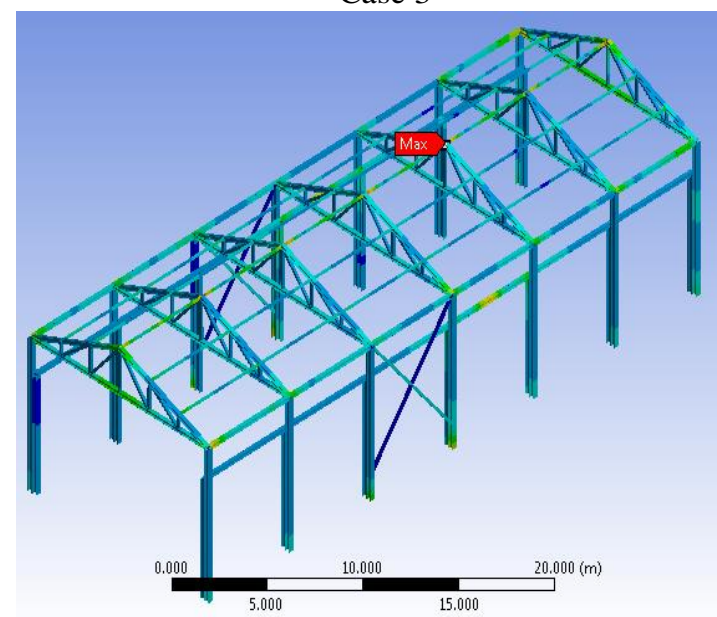

Fig. 30. Distribution of the maximum combined stresses Case 4 of load combination

the external loads of the hall, as it is supported by its own pillars.

The combined load cases are presented in Table 4 , and the graphs for maximum displacements are given in Fig. 32, and for the maximum stresses combined in Fig. 33.

Table 4. Combined load cases

\begin{tabular}{|l|l|}
\hline Case 1c & $\begin{array}{l}1.1 \text { Permanent weights }+2.13 \text { Snow } \\
\text { weight }\end{array}$ \\
\hline Case 2c & $\begin{array}{l}\text { 1.1 Permanent weights }+1.2 \text { Useful } \\
\text { (technological) weight }+1.2 \text { Cross wind }\end{array}$ \\
\hline Case 3c & $\begin{array}{l}\text { 1.1 Permanent weights }+1.2 \text { Useful } \\
\text { (technological) weight }+0.9 \text { (2.13 Snow } \\
\text { weight }+1.2 \text { Cross wind) }\end{array}$ \\
\hline Case 4c & $\begin{array}{l}\text { 1.1 Permanent weights }+1.2 \text { Useful } \\
\text { (technological) weight }+0.9 \text { (2.13 Snow } \\
\text { weight }+1.2 \text { Cross wind) }\end{array}$ \\
\hline
\end{tabular}

In the case of a cross-accelerating seismicity, the track support beam has lower displacements than the norms (arrow / bar length <1/600), see Fig. 31. 


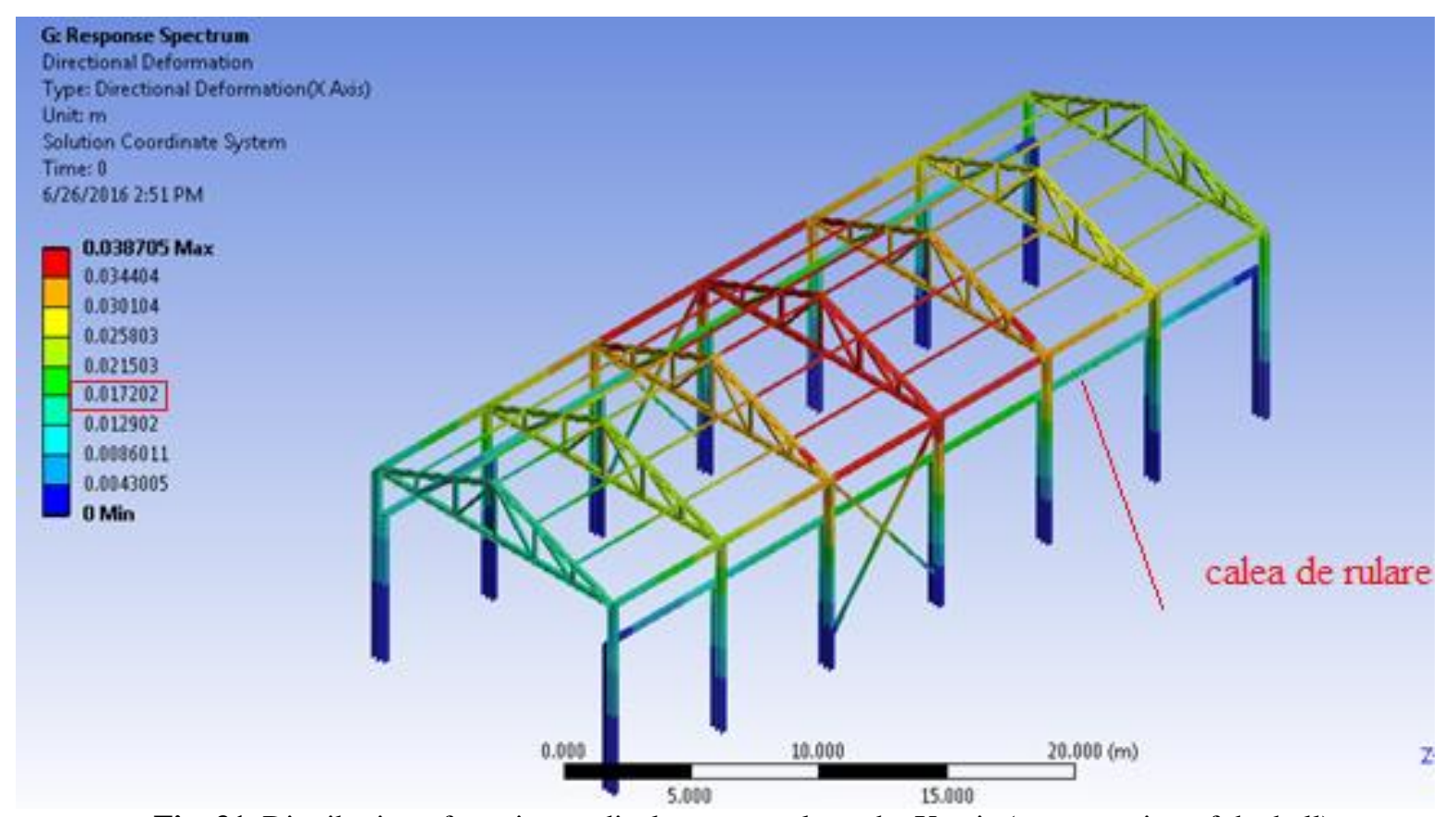

Fig. 31. Distribution of maximum displacements along the $\mathrm{X}$ axis (cross-section of the hall)

\section{REFERENCES}

Total maximum displacement in $\mathrm{mm}$ in cases of combining loads

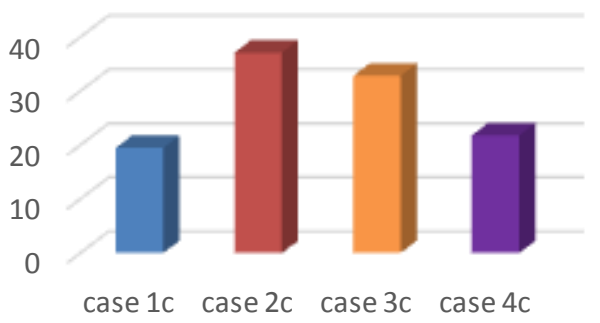

Fig. 32

Maximum combined stress in $\mathrm{MPa}$ when combining loads

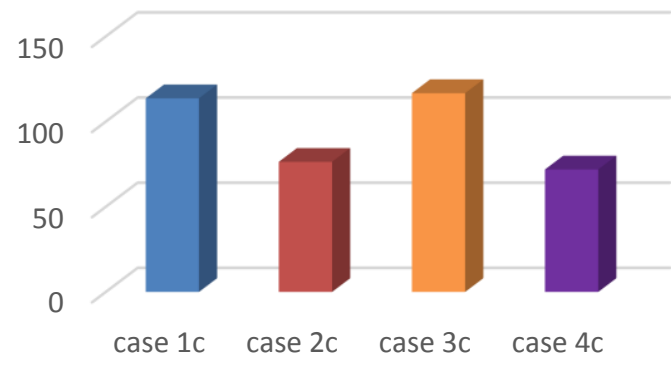

Fig. 33.

In conclusion, it is absolutely necessary to take into account the effects the snow loads, wind pressure, seismic activities can have on the structure, and an important task that must be taken into account is their own weight because the structure can cede only by the action of this task without the involvement of other external forces
1. Micu I., Boazu D., Calculul de rezistență a unei hale industriale prevăzută cu pod rulant, master thesis, "Dunarea de Jos" University, 2016.

2. Dablan C., Juncan N., Varga A., Șerban D., Construcții metalice, Editia a II-a, Editura Didactica și Pedagogica, 1976.

3. PopescuV., Construcții metalice industriale (hale, constructii cu etaje, construcctii industriale auxiliare), Editura Tehnică, București, 1961.

4. Ghid de proiectare Hale metalice - apcmr.ro, http://www.mdrap.ro/userfiles/reglementari/Dom eniul_VI/VI_16_GP_078_2003.pdf

5. Les portiques à fermes treillis - Notes sur les pratiques techniques, https://notech. franceserv.com/portique-a-ferme-treillis.html

6. *** Support Resource, shttps://www.ansys.com/academic/free-studentproducts/support-resources

7. Gavrilescu I., Boazu D., Analiză cu elemente finite. Implementare. Calcul numeric, Editura Europlus, Galați, 2006.

8. Cerbu C., Popa A.C.V., Modelarea Structurilor Mecanice (Analysis of the Mechanical Structures), Editura Universităţii Transilvania din Braşov, 2013, ISBN978-606-19-0331-3.

9. Popa A.C.V., Cerbu C., Introducere in Metoda Elementelor Finite (Introductionin in Finite Element Method), Editura Universităţii Transilvania din Braşov (Publisher), 2013, ISBN978-606-19-0332-0.

10. Curtu I., Ciofoaia V., Cerbu C., Kuchar P., Botiş M. et al., Rezistenţa materialelor (Strength of materials), vol. III, Editura Infomarket Braşov, ISBN973-8204-51-8, 2003.

11. Mateescu D., Constructii metalice - calculul și proiectarea elementelor din oțel, București, 1988. 